\title{
Technology competencies required by secondary school graduates in maintenance, servicing and repairing of electronic machines for agribusiness occupations to minimize wastage
}

\author{
Olaitan, S. O., Asogwa, V. C. ${ }^{*}$ and Abu, Mohammed \\ Department of Vocational Teacher Education, University of Nigeria, Nsukka, Enugu State, Nigeria. \\ Accepted 11 June, 2012
}

\begin{abstract}
This study focused on technology competencies required by secondary school graduates in maintenance, servicing and repairing of electronic machines for agribusiness occupations to minimize wastage. Three research questions and three hypotheses guided the study. The study made use of survey and functions of industry designs. It was carried out in Enugu State, Nigeria. The population for the study was 73, made up of 13 teachers of computer education and 60 computer and phone technicians. A 47 skill item questionnaire was used for data collection. Five experts validated the instrument. Split half technique and Pearson product moment correlation method were used to determine the internal consistency of the instrument. A reliability coefficient of 0.86 was obtained. Seventy three copies of the instrument were administered to the respondents. All the copies were retrieved and analyzed using mean and standard deviation to answer the research questions and t-test statistic to test the hypotheses. The study found out that 19 competencies in maintenance, servicing and repairing of computer, 15 competencies in maintenance, servicing and repairing of internet and 13 competencies in maintenance, servicing and repairing of phone were required by secondary school graduates for success in e-waste management in agribusiness. It was therefore recommended that the findings of this study be utilized by skill acquisition centres to train secondary school graduates for employment in maintenance, servicing and repairing of computer, internet and phone.
\end{abstract}

Key words: Agribusiness, e-waste, e-waste management, technology competencies, training.

\section{INTRODUCTION}

Agribusiness comprises all buying and selling activities of agricultural inputs and outputs. Weick (2001) stated that agribusiness is a generic term for the various businesses involved in food production including farming, seed supply, agric-chemicals, farm machinery, wholesale and distribution, processing, marketing and retail sales. Davis and Golberg in Nwibu (2006) explained agribusiness as the sum of all operations involved in the manufacturing and distribution of farm commodities and items made

\footnotetext{
*Corresponding author. E-mail: asovinchidi@yahoo.com.
}

from them. Olaitan et al. (2010) simplified agribusiness as the sum of all the economic activities involved in distribution, marketing and supplying of farm inputs to the farmers and farm outputs to the target consumers. Nwankwo et al. (2010) emphasized that modern day business are conducted and facilitated through the use of telephones, fax machines and computer, and communication networks through the internet. This phenomenon, the authors clarified, has given birth to the contemporary e-commerce, e-government, e-medicine, e-banking, eeducation among others. Gazette (2008) explained that the $e$ stands for electronics in today's technology language. In the area of the study, most electronic 
machines company used to facilitate agribusiness include telephone, computer and internet. These e-machines become e-waste when they are considered out of use in agribusiness due to malfunctioning.

E-waste, in the opinion of Kozlan (2010), is all electronic equipment or products with power plug, and batteries which have become obsolete due to advancement in technology, changes in fashion, style and status, and nearing the end of their useful life.

The author continued that e-waste encompasses over growing range of obsolete electronic devices such as computer, savers, main frames, monitors, televisions and display devices, telecommunication devices such as cellular phones and pagers, calculators, audio and video devices, printers, scanners and so on. The Environmental Protection Agency (2007) reported that about 50 million tones of e-waste are produced every year especially from developing countries. The agency estimated that in 2006 and 2007 , only 15 to $20 \%$ of e-waste was recycled, the rest went directly into landfills and incinerators. Morgan (2006) while describing e-waste as loosely discarded surplus, obsolete or broken electrical or electronic devices, stressed that it causes serious health and pollution problems if not well-managed. Some electronic scrap components contain contaminants such as lead, cadmium, beryllium, mercury and brominated frame retardants. The author cautioned that recycling and disposal of e-waste as a means of management may involve significant risks to workers and communities. Chea (2007) stated that due to the lack of government legislations on e-waste management, standards for disposal, proper mechanism for handling these toxic hitech products, mostly end up in landfills or partly recycled in an unhygienic conditions and partly thrown into waste streams.

E-waste management, in this study, involves all effort being made to elongate the life span of electronic machines through maintenance, servicing and repairs to make the e-machines functional for reuse in agribusiness. Nick in Gazette (2008) suggested that individual or companies should consider re-using electronic devices before throwing them out or recycling them. The author advised that if the product still functions, one should consider passing it on to friends or family or donating them to charity or second hand stores. Warren in Gazette (2008) criticized recycling and burning as the easiest means of e-waste management. The author buttressed that electronic devices should be maintained, serviced and repaired to increase their life cycle. It should be given to friends, families or returned to the manufacturers through their customers.

In the area of the study, data for e-waste produced yearly is not available and there is no electronic company available to recycle the e-waste. The commonest way of e-waste management, as observed by the researchers, is disposing unusable electronic devices such as computer and cell phone by burning or keeping them in the house for decorative purposes. Gazette (2008) stated that manufacturing companies such as Sony Erickson, Sony Panasonic, Motorola, Nokia, and Samsung have certified that maintenance, servicing and repairing of e-devices for re-use remain the best e-waste management, and ewaste management through maintenance, servicing and repair could be engaged in by secondary school graduates if they are equipped with the technical knowhow or skills. Secondary school graduates, in the context of this study, are those individuals who have completed six years of secondary school education but could not secure admission into any higher institution or employed in any job. Olaitan et al. (2009) observed that unemployed secondary school graduates have no means of survival except by depending on their parents. This indicates that they need to be employed to reduce poverty. E-waste management in agribusiness could provide good employment opportunity for this class of graduates if they possess the technology competencies in maintenance, servicing and repairing of e-waste.

Technology in the submission of Quirk (1995) involves new machines (electrical and electronics), equipment, and ways of doing things that are based on modern knowledge about science and computers. Competency in the statement of Olaitan and Ali (1997) is the successful performance of a task through the use of knowledge, skills, attitude and judgement. In reference to this study, technology competencies involve the knowledge, skills and attitude required by secondary school graduates for maintenance, servicing and repairing of e-waste for reuse and reduction of environmental pollution in the area of the study. The secondary school graduates could acquire technology competencies through training module in ewaste management.

Training as explained by Onuka (2008) is a skill acquisition process through which learners are taught new knowledge and skills and how to apply them. The author further stated that the objective of training individuals in an occupation such as e-waste management is to assist them to acquire professional skills for establishing and/or improving their business. Training packages in an occupation are better organized in modules. A module, in the view of Olaitan and Ali (1997), is a unit of standard measurement. It is a segment of an instructional programme. In this study, training modules refer to segments of a skill acquisition through which learners are exposed to the competencies in e-waste management for easy learning and mastery by the learners. If secondary school graduates are exposed to the technology competency training modules in ewaste management, it could provide them with self or paid employment in e-machines in agribusiness.

\section{The purpose of the study}

The purpose of the study, therefore, is to identify 
technology competencies required by secondary school graduates in maintenance, servicing and repairing of electronic machines for agribusiness occupations to minimize wastage. Specifically, the study sought to identify competencies in maintenance, servicing and repairing of computer, internet and phone.

\section{Research questions}

What are the competencies required by secondary school graduates in:

(1) Maintenance, servicing and repairing of computer?

(2) Maintenance, servicing and repairing of internet?

(3) Maintenance, servicing and repairing of phone?

\section{Research hypothesis}

There is no significant difference in the mean ratings of the responses of teachers of computer education and computer and phone technicians on the competencies required by secondary school graduates in maintenance, servicing and repairing of computer, internet and phone.

\section{METHODOLOGY}

Three research questions were developed and answered by the study and three hypotheses were formulated and tested at 0.05 level of significance $(P \leq 0.05)$.

Survey research and functions of industry designs were adopted for the study. Olaitan et al. (2000) stated that survey research design is the plan, structure and strategy that the investigator wants to adopt in order to obtain solution to research problems using questionnaire in collecting, analyzing and interpreting the data. Olaitan et al. (1999) described functions of industry as a design in which development of a training programme is derived from the basic functional areas of an industry or teaching operational divisions or development of an industry. The two designs were suitable for this study since it used questionnaire to obtain data and develop a training module based on the functional areas of e-waste management.

The study was carried out in Enugu State, Nigeria. The population for the study was 73, made up of 13 teachers of computer education in universities and 60 phone and computer technicians. The population was small and therefore, the entire population constituted the sample for the study.

A 47 skill item questionnaire was developed from literature reviewed and information from technicians in the phone and computer maintenance firms and used for data collection. The questionnaire had a four-point response scale options of highly required $(H R)$, slightly required $(S R)$, required $(R)$ and not required (NR). Five experts validated the instrument, three were from the Department of Vocational Teacher Education (Computer), and two were from the phone and computer maintenance firms. Teachers of computer education are those individuals professionally trained to equip students with knowledge and skills in computer programmes such as computer operations, programming, maintenance, servicing and repairing.

A technician, in the explanation of Hornby (2006), is an individual whose job is keeping a particular type of equipment such as computer and phone in a good condition. Their corrections and suggestions were used to produce the final copy of the questionnaire. Split-half technique and Pearson product moment correlation method were adopted to determine the internal consistency of the instrument. A reliability coefficient of 0.86 was obtained. Six research assistants were hired and briefed on how to handle the questionnaire while administering them on the respondents. All the copies of the questionnaire were retrieved and analyzed.

Weighted mean and standard deviation were used to answer the research questions, while t-test statistic was used to test the hypothesis of no significant difference. A cut-off point (arithmetic mean) of 2.50 was used for decision-making.

Any item with a mean rating of $\geq 2.50$ was regarded as a competency item that was required while any competency item with a mean of $<2.50$ was regarded as not required. Also, any item with a standard deviation 0.00 and 1.96 indicated that the respondents were close to the mean and not too far from one another in their responses. The null hypothesis of no significant difference was accepted for any item whose t-calculated value was less than the ttable value while it was rejected for any item whose t-calculated value was greater than the t-table value.

\section{RESULTS}

The results of the study were obtained from the research questions answered and the hypotheses tested. Table 1 revealed that all the 19 competency items had their mean values ranged from 3.03 to 3.94 . This showed that the mean values were above the cut-off point of 2.50 , indicating that the respondents agreed that the items were competencies required by secondary school graduates in maintenance, servicing and repairing of computer. The table also showed that the standard deviation of the items ranged from 0.58 to 1.14 , indicating that the respondents were not too far from the mean and from the opinion of one another in their responses. The table revealed that all the 19 items had their t-calculated values less than their t-table values at probability of 0.05 level of significance and $71^{\circ}$ of freedom. This indicated that there was no significant difference in the mean ratings of the responses of the two groups of respondents on the competencies required by secondary school graduates in maintenance, servicing and repairing of computer.

Table 2 revealed that all the 15 competency items had their mean values ranged from 3.25 to 3.96 . This showed that the mean values were above the cut-off points of 2.50 , indicating that the respondents agreed that the items were the competencies required by secondary school graduates in maintenance, servicing and repairing of internet. The table also showed that the standard deviation of the items ranged from 0.71 to 1.09 , indicating that the respondents were not too far from the mean and from the opinion of one another in their responses. The table revealed that all the 15 items had their t-calculated values, less than their t-table values at the probability of $\leq$ 0.05 level of significance and $71^{\circ}$ of freedom. This indicated that there was no significant difference in the mean ratings of the responses of the two groups of 
Table 1. Mean ratings and t-test of the responses of the teachers of computer education and computer technicians on competencies required by secondary school graduates in maintenance, servicing and repairing of computer.

\begin{tabular}{|c|c|c|c|c|c|c|c|}
\hline $\mathbf{S} / \mathbf{N}$ & Item statement & $\bar{X}_{r}$ & $\bar{X}_{1}$ & $\bar{X}_{2}$ & SD & t-cal & Rmks \\
\hline \multicolumn{8}{|c|}{ Maintenance $M-A_{1}$, ability to: } \\
\hline 1 & Switch off computer and its accessories after use & 3.49 & 3.26 & 2.40 & 0.80 & *1.19 & ${ }^{*} \mathrm{NS}$ \\
\hline 2 & Install and update a strong anti-virus software to protect the computer & 3.59 & 3.11 & 1.97 & 0.89 & 0.39 & ${ }^{*} \mathrm{NS}$ \\
\hline 3 & $\begin{array}{l}\text { Power computer and its accessories using a high quality surge } \\
\text { protector like UPS }\end{array}$ & 3.94 & 3.72 & 3.63 & 0.90 & 1.25 & ${ }^{*} \mathrm{NS}$ \\
\hline 4 & Stabilize the current supply with an adequate voltage stabilizer & 3.18 & 3.26 & 3.42 & 0.58 & 1.02 & ${ }^{*} \mathrm{NS}$ \\
\hline 5 & Provide adequate ventilation for the computer in operation & 3.68 & 3.90 & 3.82 & 0.99 & 0.71 & ${ }^{*} \mathrm{NS}$ \\
\hline 6 & Dust computer units regularly & 3.58 & 3.67 & 2.47 & 0.83 & 0.81 & ${ }^{\star} \mathrm{NS}$ \\
\hline 7 & Keep computer in a safe, dry and cool working condition & 3.53 & 3.08 & 2.86 & 1.01 & 0.91 & ${ }^{*} \mathrm{NS}$ \\
\hline 8 & Cover computer if not in use for a long time & 3.88 & 3.33 & 2.12 & 0.98 & 0.96 & ${ }^{*} \mathrm{NS}$ \\
\hline \multicolumn{8}{|c|}{ Servicing $M-A_{2}$} \\
\hline 9 & Recharge or change primary battery if weak & 3.60 & 3.50 & 2.28 & 1.08 & 0.29 & ${ }^{*} \mathrm{NS}$ \\
\hline 10 & Straighten the bent pins on the keyboard pot or replace if damaged & 3.62 & 3.11 & 2.81 & 0.97 & 0.26 & ${ }^{*} \mathrm{NS}$ \\
\hline 11 & Dispense dust out of the computer system with appropriate gadget & 3.18 & 3.26 & 3.42 & 0.58 & 1.02 & ${ }^{*} \mathrm{NS}$ \\
\hline 12 & Clean the mother board with brush soaked in methylated spirit or fuel & 3.03 & 3.91 & 3.76 & 0.79 & 0.67 & ${ }^{*} \mathrm{NS}$ \\
\hline 13 & Press sockets to ensure correct tightening & 3.03 & 3.91 & 3.76 & 0.79 & 0.67 & ${ }^{*} \mathrm{NS}$ \\
\hline 14 & Grease/oil moving parts of the computer like ejector & 3.06 & 3.96 & 3.40 & 0.70 & 0.34 & ${ }^{*} \mathrm{NS}$ \\
\hline \multicolumn{8}{|c|}{ Repairing $M-A_{3}$} \\
\hline 15 & Connect all cables correctly & 3.94 & 3.72 & 3.68 & 0.90 & 1.25 & \&NS \\
\hline 16 & Boot the system for functionality & 3.19 & 3.73 & 3.65 & 1.14 & 1.21 & ${ }^{*} \mathrm{NS}$ \\
\hline 17 & Troubleshoot to identify the fault & 3.36 & 3.98 & 3.98 & 0.81 & 0.85 & ${ }^{*} \mathrm{NS}$ \\
\hline 18 & Remove the damaged part and replace with recommended part & 3.88 & 3.99 & 3.79 & 0.95 & 1.01 & ${ }^{*} \mathrm{NS}$ \\
\hline 19 & Reboot the system and test for functionality & 3.58 & 3.42 & 3.18 & 1.02 & 0.23 & ${ }^{*} \mathrm{NS}$ \\
\hline
\end{tabular}

$N=43 ; 13$ teachers and 30 computer technicians. $M=$ Module, $\bar{X}_{r}=$ mean required, $\bar{X}_{1}=$ mean of teachers, $\bar{X}_{2}=$ mean of technicians, SD = standard deviation, $\mathrm{t}$-table $=1.96, \mathrm{t}$-cal. $=\mathrm{t}$-calculated values, $\mathrm{S}=$ significant, $\mathrm{NS}-$ not significant, ${ }^{*}=$ required, ${ }^{\text {** }}$ not required. $\mathrm{Rmks}$, remark.

respondents on the competencies required by secondary school graduates in maintenance, servicing and repairing of internet.

Table 3 revealed that all the 13 competency items had their mean values ranged from 3.06 to 3.94. This showed that the mean values were above the cut-off point of 2.50 , indicating that the respondents agreed that the items were competencies required by secondary school graduates in maintenance, servicing and repairing of computer. The table also showed that the standard deviation of the item ranged from 0.39 to 1.20 , indicating that the respondents were not too far from the mean and from the opinion of one another in their responses. The table revealed that all the 13 items had their t-calculated values less than their t-table values at the probability of $\leq$ 0.05 level of significance and $71^{\circ}$ of freedom. This indicated that there was no significant difference in the mean ratings of the responses of the two groups of respondents on the competencies required by secondary school graduates in maintenance, servicing and repairing of phone.

\section{DISCUSSION}

The result of the study revealed that 19 competencies in maintenance, servicing and repairing of computer, 15 competencies in maintenance, servicing and repairing of internet and 13 competencies in maintenance, servicing and repairing of phone are required by secondary school graduates for success in e-waste management in agribusiness.

The findings of the study afore stated are in agreement with the findings of Olaitan et al. (2010) in a study on technology skills required for capacity building of instructors in teaching agribusiness to students in schools of agriculture in south eastern Nigeria, where it was found out that the instructors needed capacity building in skills in the application of computer and internet for effective teaching of agribusiness to their students in schools 
Table 2. Mean ratings and t-test analysis of the responses of the teachers of computer education and computer technicians on competencies required by secondary school graduates in maintenance, servicing and repairing of internet.

\begin{tabular}{|c|c|c|c|c|c|c|c|}
\hline $\mathbf{S} / \mathbf{N}$ & Item statement & $\bar{X}_{r}$ & $\bar{X}_{1}$ & $\bar{X}_{2}$ & SD & t-cal & Rmks \\
\hline \multicolumn{8}{|c|}{ Maintenance $M-B_{1}$, ability to: } \\
\hline 1 & $\begin{array}{l}\text { Load internet with adequate number of computers that match } \\
\text { the capacity of the saver }\end{array}$ & 3.62 & 3.49 & 3.22 & 0.74 & 0.54 & ${ }^{*} \mathrm{NS}$ \\
\hline 2 & Supply saver with correct power voltage & 3.94 & 3.72 & 3.68 & 0.90 & 1.25 & ${ }^{*} \mathrm{NS}$ \\
\hline 3 & Keep the saver in a safe, dry and cool working condition & 3.88 & 3.99 & 3.79 & 0.95 & 1.01 & ${ }^{*} \mathrm{NS}$ \\
\hline 4 & Dust the saver regularly & 3.36 & 3.98 & 3.78 & 0.81 & 0.85 & ${ }^{*} \mathrm{NS}$ \\
\hline 5 & Load credit card regularly & 3.96 & 3.74 & 3.68 & 0.90 & 1.25 & ${ }^{*} \mathrm{NS}$ \\
\hline \multicolumn{8}{|c|}{ Servicing $M-B_{2}$} \\
\hline 6 & Disconnect the saver from power supply & 3.74 & 3.63 & 3.53 & 0.76 & 0.32 & ${ }^{*} N S$ \\
\hline 7 & Disengage the saver into parts & 3.25 & 3.63 & 3.36 & 0.71 & 0.19 & ${ }^{*} N S$ \\
\hline 8 & Dispense dust from the disengaged parts & 3.58 & 3.42 & 3.18 & 1.02 & 0.23 & ${ }^{*} \mathrm{NS}$ \\
\hline 9 & Clean parts with methylated spirit or fuel and dry & 3.67 & 3.89 & 3.81 & 0.98 & 0.70 & ${ }^{*} \mathrm{NS}$ \\
\hline 10 & Couple back the parts and test for functionality & 3.92 & 3.70 & 3.61 & 0.88 & 1.23 & ${ }^{*} \mathrm{NS}$ \\
\hline \multicolumn{8}{|c|}{ Repairing $M-B_{3}$} \\
\hline 11 & Connect saver to power supply & 3.57 & 3.66 & 2.46 & 0.82 & 0.80 & ${ }^{*} \mathrm{NS}$ \\
\hline 12 & Troubleshoot saver to identify fault & 3.51 & 3.06 & 2.84 & 1.00 & 0.89 & ${ }^{*} \mathrm{NS}$ \\
\hline 13 & Loosen saver into major parts & 3.85 & 3.30 & 2.09 & 0.95 & 0.93 & ${ }^{*} N S$ \\
\hline 14 & Remove faulty part(s) and replace with recommended part(s) & 3.61 & 2.50 & 2.29 & 1.09 & 0.29 & ${ }^{*} N S$ \\
\hline 15 & Couple back the parts and test for functionality & 3.59 & 3.11 & 1.97 & 0.79 & 0.39 & ${ }^{*} \mathrm{NS}$ \\
\hline
\end{tabular}

$N=43 ; 13$ teachers and 30 computer technicians. $M=$ module, $\bar{X}_{r}=$ mean required, $\bar{X}_{1}=$ mean of teachers, $\bar{X}_{2}=$ mean of technicians, $\mathrm{SD}=$ standard deviation, $\mathrm{t}$-table $=1.96, \mathrm{t}$-cal. $=\mathrm{t}$-calculated values, $\mathrm{S}=$ significant, $\mathrm{NS}-$ not significant, ${ }^{*}=$ required, ${ }^{\star *}$ not required. Rmks, remark.

Table 3. Mean ratings and t-test analysis of the responses of teachers of computer education and phone technicians on the competencies required by secondary school graduates in maintenance, servicing and repairing of phone.

\begin{tabular}{|c|c|c|c|c|c|c|c|}
\hline $\mathbf{S} / \mathbf{N}$ & Item statement & $\bar{X}_{r}$ & $\overline{\mathrm{X}}_{1}$ & $\bar{X}_{2}$ & SD & t-cal & Rmks \\
\hline \multicolumn{8}{|c|}{ Maintenance $M-C_{1}$, ability to: } \\
\hline 1 & Put phone in a waterproof leather bag & 3.91 & 3.68 & 3.81 & 0.99 & 0.71 & *NS \\
\hline 2 & Charge the battery when down or replace if weak & 3.70 & 3.92 & 3.61 & 0.90 & 1.24 & ${ }^{*} \mathrm{NS}$ \\
\hline 3 & Clean dust from phone regularly & 2.07 & 3.52 & 2.85 & 1.00 & 0.90 & *NS \\
\hline 4 & Unplug phone from power supply when fully charged & 3.33 & 3.86 & 2.12 & 0.96 & 0.95 & *NS \\
\hline \multicolumn{8}{|c|}{ Servicing, $\mathrm{M}-\mathrm{C}_{2}$} \\
\hline 5 & Disengage phone into parts & 3.27 & 3.19 & 3.43 & 0.59 & 1.20 & ${ }^{*} \mathrm{NS}$ \\
\hline 6 & Dispense dust from the disengaged parts & 3.26 & 3.20 & 3.40 & 0.50 & 1.03 & ${ }^{*} \mathrm{NS}$ \\
\hline 7 & Clean the mother board with methylated spirit and dry & 3.10 & 3.59 & 2.92 & 0.79 & 0.39 & ${ }^{*} \mathrm{NS}$ \\
\hline 8 & Couple the parts and test for functionality & 3.98 & 3.09 & 3.78 & 0.77 & 0.67 & ${ }^{*} \mathrm{NS}$ \\
\hline \multicolumn{8}{|c|}{ Repairing, $\mathrm{M}-\mathrm{C}_{3}$} \\
\hline 9 & Connect phone to power supply and switch on & 3.93 & 3.36 & 3.39 & 0.86 & 0.83 & *NS \\
\hline 10 & Troubleshoot to identify fault & 3.73 & 3.19 & 3.65 & 1.14 & 1.22 & ${ }^{*} \mathrm{NS}$ \\
\hline 11 & Disengage phone into parts & 3.73 & 3.94 & 3.68 & 0.90 & 1.24 & *NS \\
\hline 12 & Remove faulty part(s) and replace with recommended part(s) & 3.95 & 3.06 & 3.40 & 0.70 & 0.34 & ${ }^{*} \mathrm{NS}$ \\
\hline 13 & Couple the parts back and test for functionality & 3.70 & 3.19 & 3.66 & 1.15 & 1.21 & ${ }^{*} \mathrm{NS}$ \\
\hline
\end{tabular}

$N=43 ; 13$ teachers and 30 computer technicians. $M=$ module, $\bar{X}_{r}=$ mean required, $\bar{X}_{1}=$ mean of teachers, $\bar{X}_{2}=$ mean of technicians, SD $=$ standard deviation, $\mathrm{t}$-table $=1.96, \mathrm{t}-\mathrm{cal} .=\mathrm{t}$-calculated values, $\mathrm{S}=$ significant, $\mathrm{NS}-$ not significant, ${ }^{*}=$ required, ${ }^{* *}$ not required. $\mathrm{Rmks}$, remark. 
of agriculture.

\section{CONCLUSION AND RECOMMENDATION}

The application of technologies such as computer, cell phone and internet to facilitate agribusiness requires efficient maintenance, servicing and repairing of these equipments by the business man; if these are lacking, the technologies become wasted incase of any trouble with their operations and functionality. To reduce wastage, the study therefore identified competencies in the maintenance, servicing, repairing of computer, internet and cell phone for agribusiness occupation.

It was recommended that the findings of this study be utilized by skill acquisition centres to train secondary school graduates in agribusiness on maintenance, servicing, and repairing of computer, internet and phone.

\section{REFERENCES}

Chea T (2007). America Ships Electronic Waste Overseas. Associate Press. http://biz.yahoo.com/ap/071118/exporting-e-waste.html?V=3.

Environmental Protection Agency (2007). E-waste in U.S. Retrieved 4/05/11 from http//www.on.wekipedia.org.wiki/use-waste.

Gazette M (2008). Companies Offering Options on e-waste Disposal. Retrieved 4/05/11 from http://www.e-waste.com.companies.

Hornby AS (2006). Oxford Learner's Dictionary of Current English. London: Oxford University Press.

Kozlan M (2010). What is e-waste and How Can I Get Rid of it? Four Green http://www.fourgreensteps.com/inforzone/featured/features/http: ///www.svtc.org/site/Docserver/ppcttv.2004.pdf?doclD=301.

Morgan R (2006). Tips and Tricks for Recycling Old Computers. http://www. Smartbiz.com (Retrieved 17/03/2009.

Nwankwo IN, Obunadike JC, Ughamadu U (2010). The Relevance of ICT in Improving the Quality of JSS Teachers in Onueke Education Zone of Ebonyi State. International Journal of Education Research, U.N.N. Vol. 11, No. 2.
Nwibo AS (2000). Agribusiness. Unpublished M.Sc. Lesson Note, Abonyi State University, Abakaliki.

Olaitan, Asogwa, Asouzu (2010). Technology Skills Required for Capacity Building of Instructors in Teaching Agribusiness to Students in Schools of Agriculture in South Eastern Nigeria. A paper presented at the Annual Conference of Nigerian Education Research Association.

Olaitan SO, Asogwa VC, Ompede O (2009). Entrepreneurial Competencies required by secondary school graduates in Bambara ground-nut production to enhance income in Enugu state. A paper presented at the Annual conference of Nigeria Vocational Association, University of Nigeria, Nsukka.

Olaitan SO, Nwachukwu, C. O; Onyemachi, G. A., Igbo, C. A and Ekong, E. O. (1999). Curriculum Development and Management in Vocational Technical Education. Onitsha: Cape publishers international limited.

Olaitan SO, Ali A (1997). The Making of Curriculum (Theory, Process, Product and Evaluation). Onitsha: Cape Publisher International Limited.

Olaitan SO, Ali A, Eyo EO, Sowande KG (2000). Research Skills in Education. Obosi: Pacific Publishers.

Onuka AU (2008). Development of Entrepreneurship skills training Modules for enhancing youth participation regulated cassava processing occupations in Southeast, Nigeria. Unpublished Ph.D. thesis, Department of Vocational Teacher Education, University of Nigeria, Nsukka.

Quick L (1995). Longman Dictionary of Contemporary English. Spain: Longman Group Ltd.

Weick CW (2001). Agribusiness. Retrieved 28/10/11 from http//www.en. wekipedia.org.wiki/agribusiness. 